\title{
SEATING POSITION, SEAT BELT WEARING, AND THE CONSEQUENCES IN FACIAL FRACTURES IN CAR OCCUPANTS
}

\author{
Alexandre Siqueira Franco Fonseca, Dov Goldenberg, Nivaldo Alonso, Endrigo \\ Bastos, Guilherme Stocchero, Marcus Castro Ferreira
}

\begin{abstract}
Fonseca ASF, Goldenberg D, Alonso N, Bastos E, Stocchero G, Ferreira MC. Seating position, seat belt wearing, and the consequences in facial fractures in car occupants. Clinics. 2007;62(3):289-94.
\end{abstract}

INTRODUCTION: Trauma caused by traffic accidents is among the main etiologies involved in the occurrence of facial fractures throughout the world. However, the trauma mechanisms involved are different according to the location where the study was performed, due to different conditions of development, legislation, and culture. A retrospective study was done between February 2001 and July 2006, with the purpose of determining the epidemiology and the mechanisms involved in the occurrence of facial fractures among car occupants in the metropolitan area of São Paulo.

METHODS: Data were collected from 297 patients admitted with facial fractures to the emergency room of the Hospital das Clínicas, São Paulo University Medical School. Within this period, 151 individuals had been involved in traffic accidents, among which $56(37.08 \%)$ were inside passenger cars. These were grouped based on the seating position that they were occupying at the time of the accident and the wearing of seat belts. Data concerning the number and location of fracture lines were obtained from the different groups, and a fracture/patient index (F/P I) was calculated to compare and make reference to the impact energy among these groups, for subsequent analysis and discussion.

RESULTS: 323 fracture lines occurred among 56 patients who were car occupants. By applying the F/P I, we obtained higher values in the group of rear-seat passengers who were not wearing seat belts ( 7.23 fractures per patient), followed by the group of drivers not wearing seat belts (6.33 fractures per patient), the group of front-seat passengers not wearing seat belts (5.58 fractures per patient), the group of drivers wearing seat belts (5.54 fractures per patient) and, finally, the group of front-seat passengers wearing seat belts (4.00 fractures per patient). None of the rear-seat passengers was wearing seat belts.

CONCLUSION: The data collected indicate that the driver position shows a high incidence of facial fractures, not being effectively protected by the seat belt, although the wearing of seat belts seems to have a protective role against the occurrence of facial fractures in front-seat passengers. It was not possible to evaluate the wearing of seat belts among rear-seat passengers, even though the high incidence of fractures in this group showed its high susceptibility to the occurrence of facial fractures, which highlights the need of taking protective measures against this situation.

KEYWORDS: Facial fractures. Car accidents. Epidemiology. Trauma. Seat belt.

\section{INTRODUCTION}

Previously-published epidemiological studies show that the etiology of facial fractures is variable throughout the world.

Division of Plastic Surgery, Hospital das Clinicas, Sao Paulo University Medical School, Sao Paulo, SP, Brazil.

Email: mcferrei@uol.com.br

Received for publication on January 17, 2007.

Accepted for publication on February 12, 2007
Traffic accidents are among the most frequent causes of facial fractures. ${ }^{1-4}$ Several studies reveal the influence of security items such as airbags and seat belts, ${ }^{5-7}$ but few have analyzed the effect of the seating position inside the vehicle. ${ }^{8}$ There are economic, cultural and development differences among countries that must be taken into consideration.

In 2002, the National Traffic Department (DENATRAN) reported that there were 251,876 accidents in Brazil that were severe enough to lead to significant injury or fatal- 
ity. Motor vehicle collisions are the leading cause of traumatic deaths in Brazil. In 2002, a total of 18,877 people were killed in motor vehicle collisions, and other 318,313 were injured. In the metropolitan area of São Paulo alone, more than 25,000 were victims of motor vehicle collisions.

A retrospective study with data collection and analysis of all facial fracture cases in car occupants presented to a level I trauma center (Hospital das Clínicas, São Paulo University Medical School) between February 2001 and July 2006 was performed to examine the relationship between the number of fractures that occurred in each group and the seating position and the wearing of seat belts, to determine the safest place to sit in a car for avoiding the occurrence of facial fractures.

\section{METHODS}

A retrospective analysis of all patients with facial fractures who were admitted during a 5-year period to a regional metropolitan level I trauma center (Hospital das Clínicas, São Paulo University Medical School) was conducted. Within this period, from a database of 297 patients admitted with facial fractures to the emergency room of the Institution, $151 \mathrm{had}$ been involved in traffic accidents, among which 56 (37.08\%) were inside passenger cars, $42(27.81 \%)$ were driving motorcycles, 29 (19.20\%) were pedestrians, and 22 (14.56\%) were riding bicycles. The 56 patients who were inside passenger cars were selected and grouped based on the seating position that they were occupying in the vehicle at the time of the accident and the wearing or not of seat belts. Data concerning the number and location of fracture lines were obtained from the different groups, and a fracture/patient in$\operatorname{dex}(\mathrm{F} / \mathrm{P} \mathrm{I})$ - all fracture lines divided by the number of patients in each group - was calculated to compare and allow the analysis of the safety against facial fractures in each seating position.

Data were collected from patients to fill out a protocol with the following information:

I. Personal data
a. Patient identification
b. Gender
c. Age

II. Trauma mechanism
a. Vehicle involved
b. Position in the vehicle
c. Wearing of seat belts
d. Activation of airbag
III. Clinical findings
IV. Radiological findings
V. Fracture characteristics

a. Number of fracture lines b. Bones involved:

- Frontal

- Orbit (orbital floor)

- Zigoma (Orbitozigomatic complex and arch)

- Nasal (nasal bones exclusively)

- NEO (ethmoidal cells and medial orbit)

- Maxilla

- Mandible (including condyle)

The car occupants were divided into 6 groups:

Group A - Drivers wearing seat belts;

Group B - Drivers not wearing seat belts;

Group C - Front-seat passengers wearing seat belts;

Group D - Front-seat passengers not wearing seat belts;

Group E - Rear-seat passengers wearing seat belts;

Group F - Rear-seat passengers not wearing seat belts.

Larger groups were formed by the sum of groups:

Group Drivers (regardless of wearing seat belts) $=$ A + B

Group Front-seat passengers (regardless of wearing seat belts) $=\mathrm{C}+\mathrm{D}$

Group Rear-seat passengers (regardless of wearing seat belts) $=\mathrm{E}+\mathrm{F}$

Group Car occupants wearing seat belts (regardless of seating position $)=\mathrm{A}+\mathrm{C}+\mathrm{E}$

Group Car occupants not wearing seat belts (regardless of seating position $)=\mathrm{B}+\mathrm{D}+\mathrm{F}$

The number of registered fractures refers to the number of fracture lines, regardless of the possibility of a single line affecting two or more bones. Following that pattern, in case a single bone showed 2 different fracture lines, those were counted twice, according to the number of fracture lines.

The F/P I was calculated for all of these groups to have an indirect measure of the impact on each of them.

\section{RESULTS}

The study revealed that 56 patients suffered 323 facial fractures due to being inside a car during a car accident. The average age of enrolled patients was 30.9 years. The ratio of men to women was 3.3:1.

Dividing the 56 car occupants into groups based on the seating position in the vehicle and the wearing of seat belts, the data revealed that 11 out of the 20 drivers were wearing seat belts, that 11 out of the 23 front-seat passengers were wearing seat belts, and that none of the rear-seat passengers was wearing seat belts (Table 1). Among drivers wearing or not wearing seat belts, 61 and 57 fracture lines were found, respectively; among front-seat passengers wearing or not wearing seat belts, 44 and 67 fracture lines were found, respectively. Rear-seat passengers had 94 fracture lines, with none of them wearing seat belts (Table 2). 
Table 1 - Number of patients per group.

\begin{tabular}{lccc}
\hline Number of Patients & $\begin{array}{c}\text { With Seat } \\
\text { Belt }\end{array}$ & $\begin{array}{c}\text { Without } \\
\text { Seat Belt }\end{array}$ & Total \\
\hline Driver & 10 & 10 & 20 \\
Front Passanger & 11 & 12 & 23 \\
Rear Passanger & 0 & 13 & 13 \\
Total & 21 & 35 & 56 \\
\hline
\end{tabular}

Table 2 - Number of fracture lines per group.

\begin{tabular}{lccc}
\hline Number of Fractures & $\begin{array}{c}\text { With Seat } \\
\text { Belt }\end{array}$ & $\begin{array}{c}\text { Without } \\
\text { Seat Belt }\end{array}$ & Total \\
\hline Driver & 60 & 58 & 118 \\
Front Passanger & 44 & 67 & 111 \\
Rear Passanger & 0 & 94 & 94 \\
Total & 104 & 219 & 323 \\
\hline
\end{tabular}

The highest F/P I was found among rear-seat passengers ( 7.23 fractures per patient) followed by drivers wearing seat belts (6.00 fractures per patient), drivers not wearing seat belts (5.80 fractures per patient), front-seat passengers not wearing seat belts (5.58 fractures per patient), and front-seat passengers wearing seat belts (4.00 fractures per patient) (Table 3).

Table 3 - F/P I (number of fracture lines per patient) applied to different groups.

\begin{tabular}{lccc}
\hline F/P I & $\begin{array}{c}\text { With Seat } \\
\text { Belt }\end{array}$ & $\begin{array}{c}\text { Without } \\
\text { Seat Belt }\end{array}$ & Total \\
\hline Driver & 6.00 & 5.80 & 5.9 \\
Front Passanger & 4.00 & 5.58 & 4.82 \\
Rear Passanger & 0 & 7.23 & 7.23 \\
Total & 4.95 & 6.25 & 5.76 \\
\hline
\end{tabular}

When the F/P I was applied to seating positions regardless of seat belt wearing, the highest F/P I was found in the rear passenger position (7.23 fractures per patient), followed by the driver position (5.9 fractures per patient), and the front passenger position (4.82 fractures per patient) (Table 3).

Patients not wearing seat belts had a higher F/P I (6.41 fractures per patient) than patients wearing seat belts (4.77 fractures per patient) (Table 3).

It was not possible to analyze data concerning the protection provided by airbags, because none of the passenger cars carried such devices.

\section{DISCUSSION}

Epidemiological studies vary due to many factors depending on where and when the studies take place. ${ }^{1-4} \mathrm{Com}-$ parison of data requires that some local factors be considered, because patterns are not universal. Throughout the world, traffic accidents are very frequent and are one of the most prevalent etiologies of facial fractures, involving mainly young men, which is in agreement with the findings of the present study. ${ }^{2,4}$

Our study took place in a level I trauma center that covers part of the metropolitan area of São Paulo, the third largest in the world. Even though traffic rules and regulations have been made stricter since 1997, when the wearing of seat belts became compulsory by the new Traffic Code, car accidents are still one of the most frequent causes of facial fractures.

Passive safety devices such as frontal airbags and side airbags have been introduced in motor vehicles, mainly in Europe and North America, with studies demonstrating their role in the protection against the occurrence of facial fractures. ${ }^{5-8}$. We had no cases in which airbag-equipped vehicles were involved. Perhaps this was because in our area, the number of cars that have this device is very low, or perhaps because in cases when the airbag was activated, it worked so well that no facial fracture occurred. Consequently, the seat belt was the only safety device that could be evaluated. This fact corroborates the need for new epidemiological studies that would be adequate for the specific conditions that exist in each location.

By analyzing car occupants, we realized that the distribution of patients with facial fractures in different seating positions was similar, with 20 patients $(35.71 \%)$ sitting in the driver seat, $23(41.07 \%)$ sitting in the front passenger seat and $13(23.21 \%)$ sitting in the rear passenger seat. If one takes into account the fact that not all vehicles commute with all their seats full, one would expect a decreasing pattern in the incidence of facial fractures among drivers, front-seat passengers, and rear-seat passengers. The distribution of patients with facial fractures according to the seating position and the wearing of seat belts were very similar as well, except for Group E-Rear-seat passengers wearing seat belts-which was an empty group.

The numerous fractures in the group of rear-seat passengers not wearing seat belts were highlighted from the numbers of fractures in other positions. There was a contrast between the 94 fractures in the group of rear-seat passengers not wearing seat belts and the 44 fractures in the group of front-seat passengers wearing seat belts, which was better studied after the F/P I was applied.

Our data demonstrate a protective effect of seat belts against facial fractures. Regardless of the seating position in the vehicle, the F/P I was $26.4 \%$ higher in the group of patients not wearing seat belts $(\mathrm{F} / \mathrm{P} \mathrm{I}=6.25)$ than in the group of those who were wearing them (F/P I = 4.95), showing greater susceptibility to the occurrence of facial fractures among those not wearing seat belts. 
However, the protective effect was not confirmed when we analyzed the wearing of seat belts in the driver position. The P/F I for drivers wearing seat belts was 6.00, and for drivers not wearing seat belts it was 5.80, i.e., there was a slight variation of $3.4 \%$ for the group of those wearing seat belts. Interestingly, the same was not true for the group of front-seat passengers, which showed a F/P I of 4.00 for those wearing seat belts, and of 5.58 for those not wearing seat belts, which represents a difference of $39.5 \%$, in accordance with the protective effect of seat belts. In cases when drivers were wearing seat belts, the device may have managed to keep the patient's body attached to the seat, not allowing them to be ejected, but permitting their heads to be thrown against the steering wheel, which resulted in facial fractures. Since the front passenger seat does not have a steering wheel in front of him, seat belts can be more effective in the prevention of facial fractures in this case.

It was not possible to evaluate the rear-seat passenger seats with respect to the efficacy of the wearing of seat belts, because none occupying those positions was wearing them. Indeed, those were the seating positions in which the highest F/P I values were found, showing the susceptibility of rear-seat passengers to more complex injuries, with a large number of fractures in a single patient.

The number of patients with fractures among rear-seat passengers was relatively high $(23.21 \%)$ when compared to the other groups, which alerts us to the significant role that not wearing seat belts may have in the etiology of facial fractures. A hypothesis to explain the relatively high incidence of facial fractures in rear-seat passengers is that they believe that they are better protected due to the central position that they occupy inside the vehicle and are therefore being less careful about wearing seat belts.

The high number of victims not wearing seat belts found in this study reflects the real situation of vehicle traffic in the metropolitan area of São Paulo, showing the necessity to make a greater effort to increase the wearing of seat belts by car occupants. Although current legislation imposes the wearing of seat belts for passengers in all seating positions in the vehicle, there must be an educational campaign regarding the wearing of such devices, especially in the rear seats, where such prevention may bring a significant impact in the occurrence of facial fractures. The renewal of the passenger car fleet ought to bring more security, with an increase in the use of airbags (which have already proved to be an important tool in the prevention of facial fractures ${ }^{6-8}$ ), thus reducing the incidence of fractures among drivers by interposing themselves between the driver's face and the steering wheel. A more comprehensive study of the dynamics of car accidents, mainly of those which involve rear-seat passengers, will probably bring benefits through the development of new safety devices for these commuters.

Because of the small number of patients in this study, it will be continued in order to increase in the number of cases, which will allow for a statistical analysis that will support the drawing of more definitive conclusions.

\section{CONCLUSION}

Analyzing all the aforementioned data, we emphasize that:

1- Seat belts seem to have a protective effect against the occurrence of facial fractures among front-seat passengers.

2- Drivers' seat belts have limited effectiveness against facial fractures, due to the existence of the steering wheel.

3- It was not possible to analyze the wearing of seat belts by rear-seat passengers.

4- Rear-seat passengers were highly susceptible to the occurrence of facial fractures, mainly due to the fact that none of these patients was wearing seat belts.

5- The absence of victims traveling in cars with airbags shows a local condition that is different from that in North America and Europe.

\section{RESUMO}

Fonseca ASF, GoldenbergD, Alonso N, Bastos E, Stocchero G, Ferreira MC. Posição no veículo, uso de cinto de segurança e suas conseqüências nas fraturas de face em ocupantes de carros. Clinics. 2007;62(3):289-94.

INTRODUÇÃO: Os traumatismos devidos a acidentes de trânsito estão entre as principais etiologias na ocorrência de fraturas de face em todo o mundo. No entanto os mecanismos de trauma são diferentes, conforme o local onde o estudo foi realizado, devido a condições de desenvolvimento, legislação e cultura ${ }^{1,2,3,4}$. Com o objetivo de se conhecer a epidemiologia e os mecanismos envolvidos na ocorrência de fraturas de face em ocupantes de automóveis na região metropolitana de São Paulo, foi realizado um estudo retrospectivo entre Fevereiro de 2001 e Julho de 2006.

MÉTODO: Foram coletados dados de 297 pacientes admitidos com fraturas de face na sala de emergência do HC-FMUSP. Destes, 151 indivíduos estiveram envolvidos em acidentes de trânsito sendo que 56 (37,08\%) estavam 
dentro de automóveis. Estes últimos foram agrupados baseados na posição em que estavam sentados no veículo no momento do acidente e no uso de cintos de segurança. Dados referentes ao número e localização dos traços de fratura foram obtidos nos diferentes grupos e um Índice Fraturas/Paciente (IF/P) foi idealizado para comparar e avaliar o impacto nesses grupos, e para posteriormente serem analisados e discutidos.

RESULTADO: Ocorreram 323 traços de fraturas nos 56 pacientes ocupantes de carros. Aplicando-se o IF/P obtivemos maiores valores no grupo de passageiros do banco traseiro sem cinto de segurança (7,23 fraturas/ paciente), seguido pelo grupo de motoristas sem cinto de segurança (6,33 fraturas/ paciente), passageiros dianteiros sem cinto de segurança (5,58 fraturas/ paciente), motoristas com cinto de segurança (5,54 fraturas/ paciente) e por último o grupo de passageiros dianteiros com cinto de segurança (4,00 fraturas/ paciente). Nesta amostragem, não houve ocupante do banco traseiro com cinto de segurança.
CONCLUSÃO: Baseado nos dados dos pacientes e nos resultados do índice foi realizada uma análise comparandose a incidência de fraturas de face em diferentes condições dentro de um carro, levando-se em conta a posição do ocupante e o uso do cinto de segurança. Os dados indicam que a posição do motorista apresenta uma incidência elevada de fraturas de face, não oferecendo proteção efetiva mesmo com o uso do cinto de segurança, que parece ter papel protetor contra a ocorrência de fraturas de face na posição do passageiro dianteiro. Não foi possível avaliar o uso do cinto de segurança na posição do passageiro traseiro, mas a alta incidência de fraturas no grupo de ocupantes do banco traseiro sem cinto de segurança mostrou a grande suscetibilidade desta posição à ocorrência de fraturas de face, alertando para a necessidade de se tomar medidas de proteção para esta situação.

UNITERMOS: Fraturas faciais. Acidentes automobilísticos Epidemiologia. Trauma. Cinto de segurança.

\section{REFERENCES}

1. de Almeida OM. Alonso N. Fogaca WC. Rocha DL. Ferreira MC. [Facial fractures. Analysis of 130 cases]. [Portuguese] Revista do Hospital das Clinicas; Faculdade de Medicina Da Universidade de Sao Paulo. 50 Suppl:10-2, 1995.
2. Wood EB, Freer TJ. Incidence and aetiology of facial injuries resulting from motor vehicle accidents in Queensland for a three-year period. Aust Dent J. 2001;46:284-8. 
3. Klenk G. Kovacs A. Etiology and patterns of facial fractures in the United Arab Emirates. J. Craniofac Surg. 2003;14:78-84.

4. Brookes C, Wang S, McWilliams J. Maxillofacial injuries in North American vehicle crashes. Eur J Emerg Med. 2003;10:30-4.

5. Gemperli R, de Lourenco LA, Lee YS, Ferreira MC, Lodovici O. A utilidade do cinto de segurança na prevenção das fraturas de face. Rev Hosp Clin Fac Med S Paulo. 1990;45:263-7.
6. Cox D, Vincent DG, McGwin G, MacLennan PA, Holmes JD, Rue LW 3rd. Effect of restraint systems on maxillofacial injury in frontal motor vehicle collisions. J Oral Maxillofac Surg. 2004;62:571-5.

7. Murphy RX Jr, Birmingham KL, Okunski WJ, Wasser T. The influence of airbag and restraining devices on the patterns of facial trauma in motor vehicle collisions. Plast Reconstr Surg. 2000;105:516-20.

8. Mouzakes J, Koltai PJ, Kuhar S, Bernstein DS, Wing P, Salsberg E. The impact of airbags and seat belts on the incidence and severity of maxillofacial injuries in automobile accidents in New York State. Arch Otolaryngol Head Neck Surg. 2001;127:1189-93. 